\author{
Ewa Malchrowicz-Mośko \\ https://orcid.org/0000-0002-7676-1477 \\ Akademia Wychowania Fizycznego w Poznaniu \\ Wydział Nauk o Kulturze Fizycznej \\ Zakład Turystyki Sportowej \\ malchrowicz@awf.poznan.pl \\ Joanna Poczta \\ https://orcid.org/0000-0001-8825-5953 \\ Akademia Wychowania Fizycznego w Poznaniu \\ Wydział Nauk o Kulturze Fizycznej \\ Zakład Turystyki Sportowej \\ jpoczta@awf.poznan.pl
}

\title{
MĘSKIE MOTYWACJE UCZESTNICTWA W PÓŁMARATONIE - ANALIZA PORÓWNAWCZA BIEGACZY LOKALNYCH I TURYSTÓW SPORTOWYCH
}

\begin{abstract}
Abstrakt: Celem badań było poznanie motywacji do startu w półmaratonie dwóch grup biegaczy: mieszkańców Poznania (sportowców biorących udział w biegu organizowanym w miejscu zamieszkania) i aktywnych turystów sportowych, a także ocena różnic motywacji obu grup. Problem badawczy stał się istotny ze względu na wzrost popularności turystyki biegowej, która jest zachętą dla biegaczy do podejmowania aktywności fizycznej poza ich miejscem zamieszkania. Podział Freyera i Grossa (2002), w którym autorzy wyróżnili cztery typy motywów uczestnictwa w imprezach sportowych, stał się podstawą do opracowania kwestionariusza ankietowego. Badania empiryczne $(n=346)$ umożliwiły poznanie powodów uczestnictwa w wydarzeniach sportowych. Wyniki wskazują, że obiema grupami respondentów (mieszkańcy Poznania oraz turyści sportowi) kierują różne rodzaje motywacji. Najistotniejszą ich grupą dla lokalnych biegaczy okazały się motywy zorientowane na wynik, a dla turystów sportowych - motywy skierowane na przeżycia, co pozwala sądzić, że turyści sportowi podróżują przede wszystkim w celu poszukiwania silnych emocji i wrażeń.
\end{abstract}

Słowa kluczowe: motywy biegania, masowe wydarzenie sportowe, turystyka sportowa.

\section{WSTĘP}

Turystyka sportowa, przyciągając tysiące turystów i fanów na rozmaite imprezy sportowe, zawody czy mistrzostwa, stała się ważną częścią branży turystycznej. W ciągu ostatnich 30 lat (od wielkiego sukcesu igrzysk olimpijskich w Los Angeles i Barcelonie) wiele miast, regionów i krajów wdrożyło strategie systematycznego organizowania wielkich wydarzeń sportowych oraz przeznaczyło zasoby ludzkie i finansowe na możliwość przygotowania u siebie elitarnych megawydarzeń sportowych. Poszczególne państwa walczą o prawo do organizowania największych i najdroższych imprez sportowych na świecie. W wyniku tego trudnego wyścigu wiele miast i regionów decyduje się na organizację mniejszych wydarzeń sportowych z dziedziny sportu nieelitarnego (takiego jak np. bieganie), które nie wymagają drogiej infrastruktury. Ponadto od kilku lat trwa dyskusja na temat tego, czy małe i średnie wydarzenia sportowe (mara- tony i półmaratony) mogą skutecznie przyczynić się do zrównoważonego rozwoju gospodarczego miejsc turystycznych (Chappelet, 2015; Gibson, Kaplanidou, Kang, 2012; Taks, 2013; Taks, Green, Misener, Chalip, 2014).

Imprezy biegowe to atrakcje turystyki sportowej odbywające się w wielu miastach na całym świecie. Maratony i półmaratony w Europie są obecnie niezwykle popularne wśród turystów (Papanikos, 2015). Wielu entuzjastów biegania ma okazję podróżowania do niesamowitych miejsc i biegania w malowniczych krajobrazach pełnych ciekawych atrakcji turystycznych, uczestnicząc w takich imprezach, jak: ateński maraton, półmaraton na Krecie, maratony w Lizbonie, Göteborgu i Oslo, Maraton Warszawski, Międzynarodowy Maraton Pokoju w Koszycach, Szwajcarski Maraton Miejski w Lucernie, Volkswagen Maraton w Pradze, półmaratony w Genewie, Bukareszcie, Kopenhadze i Poznaniu, Półmaraton 
Wizz Air w Budapeszcie czy BMW Berlin Marathon. Interesujące jest zbadanie profilu społeczno-demograficznego uczestników imprez biegowych, ich motywacji oraz czynników wpływających na popularność turystyki biegowej i sportu nieelitarnego. Jednym z tych czynników jest rozwój ideologii healthizmu (healthism) w społeczeństwach zachodnich.

Healthizm, jako jedna z najwyższych wartości życia rozwiniętych społeczeństw, obejmuje stosowanie wielu praktyk i rozwiązań, które mają na celu wzmocnienie lub poprawę zdrowia jednostki i zachęcanie do tego innych. Jedną z takich praktyk jest upowszechnianie aktywności fizycznej. Dla tych, którzy przyjmują tę ideologię, (dobre) zdrowie jest nie tylko środkiem umożliwiającym satysfakcjonujące życie, ale także celem samym w sobie (Crawford, 1977, 1980). Takie rozumienie zdrowia wpływa na zmiany w roli medycyny, która nie tylko leczy, ale też przyjmuje podejście zapobiegawcze poprzez edukację i profilaktykę. Crawford zastosował to pojęcie po raz pierwszy w 1980 r. Opisał wtedy ideologię, która była ważnym aspektem nowej świadomości zdrowotnej American society w latach 70. XX w. Badacz uważa, że zdrowie jest stylem życia stworzonym z myślą o dobrej kondycji i sprawności oraz opiera się na indywidualnym dążeniu i budowaniu motywacji do osiągnięcia założonych celów zdrowotnych (Crawford, 1994, 2004, 2006). Healthizm odnosi się także do sposobu, w jaki podchodzimy do społecznych i moralnych wartości związanych ze zdrowiem, podczas gdy proces ten jest ściśle pozwiązany z praktykami życia codziennego oraz z tym, jak ludzie postrzegają siebie i stan swojego zdrowia w stosunku do środowiska społecznego. Świadomość ta kształtowała się w kulturze amerykańskiej wraz ze wzrostem popularności sportu dla wszystkich, co znalazło odzwierciedlenie $\mathrm{w}$ indywidualnych staraniach o zdrowie, licznych kampaniach promujących zdrowie i dostarczających coraz więcej informacji związanych z nim za pośrednictwem mediów (np. reklamy zdrowej żywności).

\section{ROZWÓJ MASOWEGO SPORTU I TURYSTYKI SPORTOWEJ W POLSCE}

W ciągu ostatnich kilku lat ideologia healthizmu rozwijała się również w Polsce. Trend ten jest szczególnie widoczny na imprezach masowych, w których Polacy chętnie uczestniczą. Ponieważ skala tego zjawiska społecznego jest ogromna, stało się ono niezwykłe i jest analizowane na wielu poziomach. Pod rozwagę brane są liczne czynniki interdyscyplinarne. Dodatkowo aktywność fizyczna Polaków dynamicznie wzrosła w ciągu ostatnich dwóch dekad. Pozytywne zmiany w tym zakresie zaczęły być obserwowane już po przemianach politycznych w 1989 r. Wcześniej Polacy byli społeczeństwem, które w porównaniu do krajów zachodnich wykazywało znacznie niż- szą aktywność fizyczną. Po przystąpieniu do Unii Europejskiej Polska znajdowała się na końcu listy krajów europejskich pod względem podejmowania aktywności fizycznej przez obywateli. Obecnie Polacy poprawili swoją pozycję i są w środku tej listy, co stanowi szybki wzrost. Ponadto zarówno media, jak i politycy starają się utrwalić ten trend, aby osoby starsze również zachęcić do uprawiania sportu (Biernat, Piątkowska, 2012; Raport "Aktywność fizyczna Polaków"..., 2015).

Na wzrost aktywności fizycznej mieszkańców naszego kraju wpłynęły także czynniki społeczne, kulturowe i ekonomiczne. Obecnie Polacy są lepiej wykształceni, zamożniejsi, mają więcej wolnego czasu, a jakość ich życia wzrosła względem poprzednich lat. Wielu przeniosło się do miast, w których dynamicznie rozwijała się infrastruktura sportowa - pływalnie, kluby fitness i ścieżki rowerowe. Zaczęli również liczniej pracować w biurach, a wcześniej - jeszcze w czasach komunizmu - wykonywali przez wiele godzin pracę fizyczną w mieście lub zajmowali się rolnictwem, w związku z czym w czasie wolnym już nie myśleli o bieganiu czy pływaniu.

Koniec lat 90. XX w. był w Polsce czasem intensywnej i szybkiej transformacji gospodarki planowej w wolnorynkową gospodarkę kapitalistyczną. Dystans między krajami zachodnimi a Polską był wówczas wyraźnie widoczny na przykładzie wielu wskaźników stylu życia, w tym sportu i rekreacji, opieki zdrowotnej, ale także sposobu odżywiania. Wtedy polskie społeczeństwo zaczęło dostosowywać się do zachodniego stylu życia. Obecnie obserwujemy coraz bardziej pozytywne postrzeganie sportu w polskim społeczeństwie. W XXI w. Polacy traktują sport jako ważny element kultury i życia społecznego. Wzrost zainteresowania sportem można także wytłumaczyć organizacją przez Polskę i Ukrainę jednego z największych megaeventów sportowych - Mistrzostw Europy w Piłce Nożnej w 2012 r. Poprzez sposób spędzania czasu wolnego można podkreślić swój status społeczny. Sport i turystyka sportowa stały się charakterystyczną cechą klasy średniej w Polsce. Szczególnie widoczna jest moda na bieganie, nie tylko we własnym mieście (Domański, 2000; Lenartowicz, Dziubiński, Jankowski, 2017; Stempień, 2015, 2016).

Mimo to Polacy są nadal bardzo podobni do mniej aktywnych sportowo mieszkańców południowoeuropejskich krajów, takich jak Grecja. Z jednej strony odbiegamy od Skandynawii, w której zdecydowana większość mieszkańców jest aktywna (Biernat, Piątkowska, 2012). Ulubionymi dyscyplinami Polaków są: jazda na rowerze (53\%), bieganie (33\% osób aktywnych fizycznie) i pływanie (29\%) (Raport „Aktywność fizyczna Polaków"..., 2015). Z drugiej strony w Polsce zapanowała moda na zdrowy i aktywny tryb życia. Na przykład imprezy biegowe są organizowane nawet $\mathrm{w}$ małych polskich miastach. Ludzie chcą dobrze wyglądać i być atrakcyjni. Wśród aktywnych fizycznie Polaków zachodzą przemiany w sposobie konsumpcji i zmieniają się wybrane formy aktywności 
fizycznej. Pod tym względem zmierzamy w kierunku wzorców zachodnich.

Sport powszechny i udział w masowych wydarzeniach sportowych dynamicznie się rozwijają. Coraz częściej Polacy stają się turystami sportowymi. Udział w zorganizowanych masowych eventach sportowych i rekreacyjnych (zwłaszcza bieganie $\mathrm{w}$ takich imprezach, jak maratony i półmaratony) stał się niezwykle atrakcyjną formą rekreacji fizycznej. Widać to przede wszystkim na przykładzie masowych wydarzeń sportowych, w których frekwencja w Polsce w ostatnich latach wzrosła o kilkaset procent, np.: Poznań Marathon (wzrost od 2000 r. o 900\%), Poznań Półmaraton (wzrost od 2008 r. o 800\%), Poznań Triathlon (wzrost od 2013 r. o 300\%), Poznań Bike Challenge (wzrost od 2014 r. o 40\%) ${ }^{1}$. Liczba takich wydarzeń i osób biorących w nich udział zwiększyła się zauważalnie od 2000 r. Każdego roku odbywa się w kraju ponad 15 dużych maratonów (mowa tu tylko o tych wydarzeniach, w których uczestnicy są liczeni w tysiącach).

Poznań to przykład miasta o liczbie mieszkańców przekraczającej 500 tys. i bardzo szerokiej ofercie wydarzeń sportowych. Co roku w mieście i regionie wielkopolskim organizowanych jest ponad 500 eventów na różnych poziomach, co plasuje Poznań w czołówce imprez biegowych w całym kraju. Obserwowana tendencja rodzi pytanie o motywy biegaczy maratonu, szczególnie ze względu na fakt, że w kontekście życia codziennego zarówno trening, jak i same maratony są swego rodzaju luksusem, ponieważ wymagają czasu i dobrego zdrowia. Treningi biegowe są bardzo wyczerpujące, a osoby uprawiające ten sport wykraczają daleko poza zakres kondycji fizycznej, w której według WHO powinna być zdrowa osoba.

\section{MOTYWACJE DO BIEGANIA W ŚWIETLE TURYSTYKI SPORTOWEJ - PRZEGLĄD LITERATURY}

Dotychczas przeprowadzono wiele badań nad motywacją biegaczy (m.in. Ogles, Masters, Richardson, 1995; Ogles, Masters, 2003), jednak niewiele jest opracowań na temat różnic między motywacjami uczestników biegowych eventów sportowych, którzy są mieszkańcami miasta organizacji zawodów, a turystami sportowymi. Ogles, Masters i Richardson (1995) wykazali, że mężczyźni biegają $\mathrm{z}$ takich powodów, jak: chęć uczestnictwa $w$ zawodach, chęć osiągania sukcesów oraz wygrywania z przeciwnikiem lub z samym sobą. Ważne jest dla nich utrzymanie zdrowia i kondycji fizycznej. Poznanie motywacji turystów sportowych, biorących udział w zawodach biegowych, jest niezwykle istotne z ekonomicznego i marketingowego punktu widzenia. Aicher, Karadakis i Eddo- sary (2015) także nie wykazali różnic pomiędzy turystami sportowymi a mieszkańcami pod względem motywacji. Ich badania zostały oparte na kwestionariuszu dystrybuowanym w Internecie. Autorzy tych badań uważają, że powinno się analizować opinie, odczucia oraz poziom emocji i satysfakcji podczas wydarzenia sportowego.

Według Schwarka turystyka sportowa może stwarzać więcej możliwości do zwiększenia intensywności doznań na poziomie zmysłowo-witalnym, emocjonalnym i społecznym (Schwark, 2006). Na większą intensywność przeżyć turysty sportowego może wpływać znajdowanie się w niecodziennej scenerii oraz nawiązywanie interakcji kulturowych i społecznych z mieszkańcami odwiedzanych obszarów. Uprawianie sportu poza miejscem zamieszkania może zatem stworzyć nową jakość, która wydaje się $\mathrm{w}$ takim stopniu pozbawiona aktywności sportowej $w$ tradycyjnym otoczeniu. Turystyka sportowa może zapewnić więcej możliwości do intensywniejszego przeżywania niż sport uprawiany w znanych warunkach w miejscu zamieszkania (Kazimierczak, Malchrowicz-Mośko, 2013). Sport i turystyka w formie turystyki sportowej tworzą wartość dodaną, wyrażającą synergiczny efekt internalizacji autotelicznych wartości turystyki i sportu. Turysta sportowy nie tylko rozwija swoje ciało, ale także wzrasta duchowo dzięki związkowi z nowym środowiskiem przyrodniczym, kulturowym i społecznym (Szczechowicz, 2015). Wszystko to może mieć wpływ na motywację do odbycia podróży sportowej. Dlatego warto sprawdzić, czy motywy biegowe są takie same wśród lokalnych biegaczy i turystów sportowych. Być może podróż w celach sportowych zapewnia turystom np. więcej okazji do zaspokojenia emocji lub potrzeb partnerskich, co wpływa na ich motywacje. Na podstawie przeglądu literatury (Kazimierczak, Malchrowicz-Mośko, 2013; Schwark, 2006; Szczechowicz, 2015) przyjęto hipotezę, że turyści sportowi są bardziej zadowoleni z udziału w półmaratonie niż sportowcy mieszkający w miejscowości, w której odbywa się dany event.

Zgodnie z teorią Zuckermana (1994) obserwujemy wzrost znaczenia przeżywania silnych emocji związanych $\mathrm{z}$ uczestnictwem $\mathrm{w}$ wydarzeniu sportowym, określając je jako poszukiwanie wrażeń. Badacz, doświadczając silnych emocji towarzyszących nastrojowi danego wydarzenia, uważa je za jeden z najważniejszych czynników wpływających na wybór i skuteczność różnych form aktywności sportowej i rekreacyjnej. Osoby uprawiające sport i rekreację częściej odczuwają potrzebę zwiększenia obciążenia i wydajności, uczestniczenia w sytuacjach stwarzających okazję do weryfikacji własnych osiągnięć, ciągłego sprawdzania się i osiągania wysokiego poziomu stymulacji. Takie zjawisko, określane jako poszukiwanie wrażeń, może być obecnie jednym z najważniejszych czynników wpływających na wybór i skuteczność różnych form aktywności sportowej i rekreacyjnej. Zgodnie z kierunkiem zmian rozwojowych we 
współczesnym sporcie oraz w turystyce i działalności rekreacyjnej - od rekreacji do emocji - uczestnicy coraz częściej poszukują ekstremalnych wrażeń związanych z samodoskonaleniem i współzawodnictwem, a przede wszystkim doświadczają ekscytującego i celowo kontrolowanego ryzyka (Walczak, Tomczak, 2011; Zuckerman, 1994). Turystyka sportowa może być również postrzegana jako emanacja ekonomii wrażeń - współcześni turyści szukają silnych emocji podczas swoich podróży. Obecnie nie wystarczy uprawianie sportu i rekreacji, aby cieszyć się wolnym czasem i czynnościami związanymi z wykorzystaniem swoich umiejętności. W dzisiejszych czasach aktywność ta opiera się raczej na zwiększeniu obciążenia i skuteczności działania. Bardziej atrakcyjne jest uczestnictwo w wydarzeniach sportowych i rekreacyjnych, które dają możliwość weryfikacji własnych osiągnięć, ciągłego stawiania sobie wyzwań i osiągania wysokiego poziomu stymulacji również w czasie wolnym. Aktualnie może to być jeden z najważniejszych czynników wpływających na wybór i skuteczność różnych form aktywności sportowej i rekreacyjnej. To może również tłumaczyć rosnącą popularność zajęć rekreacyjnych, takich jak bieganie w maratonie. Ludzie szukają form rekreacji, które dostarczają wrażeń i emocji związanych z ryzykiem, chcą walczyć z siłami natury, przeciwnikiem, sobą lub własną słabością.

Wielu badaczy jest zainteresowanych kwestią ludzkiej motywacji. Jednym z najważniejszych rezultatów badań prowadzonych od ponad 40 lat jest teoria samookreślenia (self determination theory, SDT). Jej założenia stanowią trzyczęściowy rdzeń, który jest podstawą rozwoju człowieka i składa się z psychologicznych potrzeb: autonomii, kompetencji i relacji (Deci, Ryan, 2000a, 2000b; Ryan, 1995; Ryan, Deci, 2000). Potrzeba autonomii odzwierciedla pragnienie człowieka do samostanowienia i wyborów, których dana osoba doświadcza, gdy postrzega swoje funkcjonowanie jako wynik własnych decyzji (Ryan, La Guardia, 2000). Potrzeba kompetencji odnosi się do skłonności do efektywnych interakcji w sytuacjach, które pozwalają zdobyć doświadczenie oraz zaprezentować własne umiejętności i możliwości. Z kolei potrzebę relacji można zaspokoić, gdy człowiek ma dobre relacje z bliskimi, którzy są dla niego ważni, lub gdy czuje, że przynależy do określonego kontekstu społecznego (Ryan, La Guardia, 2000).

Deci i Ryan (2000b) wspominają o indywidualnym poziomie nasycenia potrzebami psychologicznymi i ich niehierarchicznym charakterze, podkreślając ich znaczenie dla poczucia wysokiej jakości życia opartej na rozwoju psychologicznym. Środowisko, które zapewnia bodźce zaspokajające omawiane potrzeby, umożliwia samostanowienie w działaniu, czerpaną z niego satysfakcję oraz wewnętrzną lokalizację motywów podejmowanej aktywności, prowadzi do odczuwania przyjemności i utożsamiania się z działaniem nieobowiązkowym (Vlachopoulos, Michailidou, 2006). Motywacja leży u podstaw wielu najciekawszych zagadnień dotyczących sportu oraz wyników sportowych. Może być efektem oddziaływania środowiska społecznego, jakim jest np.: wpływ współzawodnictwa czy zachowań trenerów albo wpływ rozwojowy na zmienne behawioralne, np.: wytrwałość, uczenie się i wydajność (Vallerand, Deci, Ryan, 1987).

W literaturze przedmiotu pojawiła się perspektywa, która zakłada, że zachowanie człowieka może być motywowane wewnętrznie, zewnętrznie lub amotywowane (Deci, 1975; Deci, Ryan, 1985, 1991). Jest to teoretyczne podejście, które w konsekwencji zaowocowało nowymi badaniami związanymi ze sportem. Na przykład pod jego wpływem Pelletier, Tuson, Fortier, Vallerand, Brière i Blais (1995) opracowali nową miarę motywacji do uprawiania sportu, opartą na założeniach teorii Deci i Ryana. Wspomnianych sześcioro autorów, przy wykorzystaniu siedmiu podskal, które mierzą różne formy motywacji przedstawione w teorii Deci i Ryana, stworzyło skalę motywacji w sporcie (Sport Motivation Scale - SMS) (Pelletier i in., 1995; Vallerand, 1997). Jest ona narzędziem badania różnorodności procesów motywacyjnych związanych z uczestnictwem w sporcie i rozróżnia - wspomniane już - trzy wymiary: motywację wewnętrzną (intrinsic motivation), motywację zewnętrzną (extrinsic motivation) i amotywacje (amotivation). Zaproponowane siedem podskal służy do pomiaru: a) trzech rodzajów motywacji wewnętrznej, które obejmują motywację wewnętrzną ukierunkowaną na: wiedzę, osiągnięcia oraz stymulację doznań (sensation seeking); b) trzech form regulacji motywacji zewnętrznej, od najniższego do najwyższego poziomu samookreślenia, które dzielą się na regulacje zewnętrzne (nagrody i kary), introjekcję (internalizację) i identyfikację (identified, introjected and external); oraz c) amotywacji (Brière, Vallerand, Blais, Pelletier, 1995). Przedstawiona metoda - skala motywacji w sporcie (SMS) - jest bardzo ceniona w światowej literaturze z zakresu psychologii sportu. Uznaje się ją za dokładną i posiadającą wysoki poziom wewnętrznej spójności (Brière, Vallerand, Blais Pelletier, 1995). Należy też wspomnieć, że skala SMS jest szeroko wykorzystywana (nie tylko w psychologii sportu) - zastosowano ją także w badaniach masowych nad uwarunkowaniem aktywności rekreacyjnej w Grecji i Francji (Alexandris, Carroll, 1997; Alexandris, Tsorbatzoudis, Grouios, 2002). Kwestionariusz został przyjęty do badań w wielu krajach (De Pero, Amici, Benvenuti, Minganti, Capranica, Pesce, 2009; Doganis, 2000).

Inne podejście badawcze mają Curtis i McTeer (1981). Autorzy, stosując metodę niedokończonego zdania, na podstawie odpowiedzi udzielonych przez ankietowanych, ustalili, że głównymi przyczynami udziału w maratonach były: osiąganie własnych celów, wpływanie na innych oraz poprawa samopoczucia psychicznego. Summers, Sargent, Levey i Murray (1982), wykorzystując tę samą metodę, zbadali trzy powody udziału w maratonie, określili częstotliwość ich występowania, pogrupo- 
wali je $\mathrm{w}$ kategorie na podstawie podobieństwa treści i stwierdzili, że najczęściej wymieniane było osiągnięcie celów związanych z samooceną, sprawnością fizyczną oraz wpływem innych osób. Johnsgård (1985), korzystając z kwestionariusza, zbadał główne motywy biegania, a jego respondenci wskazali na znaczenie sprawności fizycznej, kontrolę nastroju pod wpływem biegania oraz budowanie własnego wizerunku. Clough, Sheper i Maugha (1989) zapytali również maratończyków o powody biegania, a poprzez analizę czynników zidentyfikowali ich sześć, według siły wpływu: wyzwanie, dbanie o formę/ zdrowie, dobre samopoczucie, czynniki społeczne, budowanie statusu i uzależnienie.

Zaczęły pojawiać się także autorskie narzędzia do badania czynników, które skłaniają ludzi do biegania w maratonach: Gill i Deeter (1988) zastosowali kwestionariusz orientacji sportowej (SOQ), za pomocą którego mierzy się orientację na osiągnięcia w sporcie; Crowne i Marlow (1960) stworzyli Marlow crowne social desirability scale (MCSD) - skalę do poszukiwania akceptacji społecznej; Carmack i Martens (1979) zastosowali kwestionariusz attentional focussing questionnaire (AFQ), pomocny $\mathrm{w}$ mierzeniu orientacji asocjacyjnej/dysocjacyjnej w sporcie; Masters, Lambert, Ogles i Jolton (Masters, Lambert, 1989; Masters, Ogles, Jolton, 1993) opracowali kwestionariusz "Skala motywacji maratończyków" / The motivations of marathoners scales (MoMS), pozwalający określać motywy maratończyków do biegania w maratonach. Freyer i Gross wyróżnili zaś cztery główne typy orientacji wśród motywów brania czynnego udziału w wydarzeniach sportowych: a) orientację społeczną, skoncentrowaną na relacjach między gośćmi; b) orientację na poszukiwanie emocji/doznań, najczęściej dotyczącą pozytywnych doświadczeń (sensation seeking orientation), w postaci np. relaksu, który jest rodzajem rekompensaty za trudy codziennego życia; c) orientację rzeczową, odnoszącą się do samych wydarzeń sportowych i ich specyfiki; $\mathrm{w}$ tym przypadku do specyfiki uprawianego sportu; d) orientację na wynik, wywołaną potrzebą utożsamienia się z sukcesem, a w przypadku niepowodzenia - potrzebą okazania współczucia i solidarności. Klasyfikacja opracowana przez Freyera i Grossa (2002) stała się podstawą do opracowania autorskiego kwestionariusza ankiety dotyczącego motywów uczestnictwa w imprezie biegowej. Kwestionariusz wykorzystano podczas kolejnego już półmaratonu zorganizowanego w Poznaniu.

\section{MATERIAŁ BADAWCZY I METODY}

Z badań Rossa (2001) wynika, że w USA młodzi mężczyźni z wyższym wykształceniem, aktywni zawodowo, są najbardziej aktywnymi uczestnikami imprez biegowych. Z kolei Roberts (2011) wykazał, że turyści spor- towi to najczęściej wykształceni mężczyźni w dobrej sytuacji ekonomicznej. Wynika to z większego w ogóle udziału mężczyzn w sporcie i konieczności ponoszenia wysokich kosztów finansowych uczestnictwa w niektórych wydarzeniach sportowych (Roberts, 2011). Dane uzyskane od organizatorów poprzednich półmaratonów w Poznaniu wskazują, że w Polsce również w półmaratonie częściej biegają mężczyźni.

Celem prezentowanych badań było poznanie motywacji do udziału w półmaratonie między dwiema grupami biegaczy płci męskiej: mieszkańcami Poznania i przybyłymi tam turystami sportowymi, oraz poznanie i ocena różnic motywacji, które prowadzą do udziału w półmaratonie mężczyzn z obu grup respondentów. Dane zebrano od uczestników w 2013 r. podczas 6. Poznań Półmaratonu, który jest jedną z najważniejszych imprez biegowych w dziedzinie sportu masowego w Polsce, skupiającą zarówno sportowców amatorów, jak i zawodowców.

Opisany w poprzednim podrozdziale podział motywów, opracowany przez Freyera i Grossa (2002), stał się podstawą do opracowania autorskiego kwestionariusza do badania motywów uczestnictwa w imprezach biegowych.

Wyniki dotyczące udziału różnych rodzajów motywów przewyższają wartość $100 \%$, ponieważ w każdej grupie motywów uczestnicy mogli zaznaczyć więcej niż jedną odpowiedź (ale maksymalnie trzy). Statystyka opisowa (wartości procentowe, średnie i odchylenia standardowe) została obliczona dla wszystkich zmiennych. W odniesieniu do różnic między odpowiedziami mieszkańców miasta i turystów sportowych zastosowano test Chisquare. Istotność statystyczną ustalono dla $p \leq 0,05$. Wszystkie analizy statystyczne przeprowadzono przy użyciu Statistica Software 10.0 (StatSoft Inc., 2011). Badania pilotażowe zostały przeprowadzone podczas poprzedniej edycji wydarzenia - 5. Poznań Półmaratonu.

Badania metodą sondażu diagnostycznego przeprowadzono osobiście, wykorzystując znormalizowane techniki wywiadu wśród 346 mężczyzn uczestniczących w 6. Poznań Półmaratonie w 2013 r., w tym 139 mieszkańców Poznania $(n=139)$ i 207 turystów sportowych $(n=207)$. Każdy z respondentów wziął udział w imprezie i dobrowolnie wypełnił kwestionariusz. Wszyscy badani turyści sportowi przybyli do Poznania, aby wziąć udział w tym półmaratonie. Próba została dobrana w sposób zapewniający dobrą reprezentatywność uzyskanych wyników. Zastosowano schemat prostej próby losowej bez zamiany. Przy określaniu liczby badanych wykorzystano informacje od organizatorów dotyczące oczekiwanej liczby uczestników wydarzenia. W obliczeniach zastosowano wzór wielkości próby dla populacji skończonej. Przyjęto założenie, że maksymalny błąd oszacowania (e), przy poziomie ufności $95 \%$, nie powinien przekraczać $4 \%$. 


\section{WYNIKI}

\subsection{CECHY SPOŁECZNO-DEMOGRAFICZNE RESPONDENTÓW - PROFIL BIEGACZA}

Większość respondentów wybranych spośród uczestników półmaratonu poznańskiego reprezentowała dwie grupy wiekowe: $26-35$ lat (40,8\%) oraz 19-25 lat (39,3\%). Kolejną liczebnie grupę stanowiły osoby w wieku 3650 lat $(13,3 \%)$, podczas gdy tylko $4,6 \%$ biegaczy zaliczało się do przedziału 51-70 lat. Uczestnicy reprezentowali różne poziomy wykształcenia, większość miała wykształcenie wyższe (46,8\%), pozostali kolejno - średnie $(29,8 \%)$ i niepełne wyższe $(19,4 \%)$, a najmniejszy udział (4\%) mieli biegacze z wykształceniem podstawowym. Większość uczestników pochodziła z terenów miejskich, takich jak: miasta liczące powyżej 500 tys. mieszkańców $(41,3 \%)$ oraz 10-100 tys. mieszkańców (40,5\%), ale byli także ma- ratończycy z obszarów wiejskich $(18,2 \%)$. Ponad połowa uczestników półmaratonu $(58,4 \%)$ zadeklarowała w kwestionariuszu aktywność zawodową, pozostali to studenci $(30,3 \%)$, emeryci $(4,0 \%)$, uczniowie szkoły średniej $(3,5 \%)$ i bezrobotni (3,8\%). W tab. 1 przedstawiono najczęściej wskazywane motywy, podzielone na cztery grupy: orientacji społecznej, orientacji emocjonalnej/poszukiwania wrażeń, orientacji rzeczowej oraz orientacji na wynik, dla wszystkich badanych mężczyzn $(n=346)$.

Ta kombinacja pozwoliła poznać motywy mężczyzn, którzy decydują się na start w półmaratonie. Najczęściej udzielaną odpowiedzią z pierwszej grupy motywów (grupa A) była chęć poczucia jedności i integracji z innymi ludźmi. Ten motyw wybrało 171 ankietowanych $(49,4 \%)$. W drugim zestawie motywów (grupa B) najważniejsza okazała się chęć przeżywania silnych emocji związanych z uczestnictwem w biegu w półmaratonie, którą zadeklarowały 223 osoby $(64,5 \%)$, oraz chęć zabawy - wskazana przez 180 respondentów (52\%). Trze-

Tabela 1. Motywy startujących w półmaratonie poznańskim mężczyzn ( $\mathrm{n}=346) \mathrm{w}$ zakresie orientacji społecznej, orientacji na przeżycia, rzeczowej oraz nastawionej na wynik

\begin{tabular}{|c|c|c|}
\hline \multirow[t]{2}{*}{ Grupy motywów } & \multicolumn{2}{|c|}{$\begin{array}{l}\text { Startujący w półmaratonie } \\
(\mathrm{n}=346)\end{array}$} \\
\hline & $\mathrm{n}$ & $\%$ \\
\hline \multicolumn{3}{|l|}{$\begin{array}{c}\text { Grupa A } \\
\text { Motywy w zakresie orientacji społecznej }\end{array}$} \\
\hline Pragnienie poczucia jedności i integracji z innymi ludźmi & 171 & 49,4 \\
\hline Pragnienie poczucia równości podczas wyścigu & 67 & 19,4 \\
\hline Panująca moda - udział w imprezach sportowych jest obecnie modny & 32 & 9,2 \\
\hline Pragnienie zdobycia uznania w oczach innych & 70 & 20,2 \\
\hline Przynależność do subkultury biegaczy & 97 & 28,4 \\
\hline \multicolumn{3}{|l|}{$\begin{array}{c}\text { Grupa B } \\
\text { Motywy w zakresie orientacji na przeżycia }\end{array}$} \\
\hline Pragnienie przeżycia silnych emocji związanych ze startem & 223 & 64,5 \\
\hline Pragnienie poczucia niezwykłej atmosfery panującej podczas całej imprezy & 164 & 47,4 \\
\hline Pragnienie dobrej zabawy & 180 & 52,0 \\
\hline Pragnienie spędzenia miło czasu / rozrywki & 93 & 26,9 \\
\hline Pragnienie wyrażenia radości, np. z powodu wygranej/sukcesu & 62 & 17,9 \\
\hline Pragnienie oderwania się od codzienności & 6 & 17,6 \\
\hline Przyciągająca atrakcyjność miasta, w którym odbywa się impreza & 19 & 5,5 \\
\hline \multicolumn{3}{|l|}{$\begin{array}{c}\text { Grupa C } \\
\begin{array}{c}\text { Motywy w zakresie orientacji rzeczowej } \\
\text { (na konkretną dyscyplinę sportową) }\end{array}\end{array}$} \\
\hline Pragnienie rozwijania pasji & 247 & 71,4 \\
\hline Przyciągająca atrakcyjność sportowej części półmaratonu & 101 & 22,0 \\
\hline Przyciągająca atrakcyjność imprezy z powodu bogatego programu imprez towarzyszących & 37 & 10,7 \\
\hline \multicolumn{3}{|l|}{$\begin{array}{c}\text { Grupa D } \\
\text { Motywy w zakresie orientacji na wynik }\end{array}$} \\
\hline Pragnienie sprawdzenia się & 254 & 73,4 \\
\hline Pragnienie osiągnięcia wyznaczonego przez siebie celu & 212 & 61,3 \\
\hline Pragnienie udziału w rywalizacji sportowej & 142 & 41,0 \\
\hline Pragnienie wygranej & 8 & 2,3 \\
\hline Wysoka (międzynarodowa) ranga imprezy sportowej & 14 & 4,0 \\
\hline \multicolumn{3}{|l|}{$\begin{array}{c}\text { Grupa E } \\
\text { Pozostałe motywy }\end{array}$} \\
\hline Pragnienie utrzymania dobrej kondycji fizycznej oraz zdrowotnej & 287 & 82,9 \\
\hline
\end{tabular}

Źródło: opracowanie własne na podstawie przeprowadzonych badań ( $\mathrm{n}=346)$. 
cia grupa motywów (C) pokazuje, że dla mężczyzn biorących udział w półmaratonie najważniejsza jest chęć rozwijania pasji związanej z bieganiem. Ten motyw wybrało 247 respondentów $(71,4 \%)$. W przypadku ostatniej grupy motywów (D) wyniki pokazują, że najważniejsza dla ankietowanych biegaczy jest chęć sprawdzenia siebie. Ten motyw, jako najczęściej wskazywany spośród wszystkich badanych grup motywów, został wybrany przez prawie 254 ankietowanych mężczyzn $(73,4 \%)$ - tab. 1. Kolejnym motywem $w$ grupie $D$, zadeklarowanym przez 212 $(61,2 \%)$ badanych osób, była chęć osiągnięcia założonego celu. W grupie E (,inne motywy") - największą liczbę wskazań respondentów, czyli 287 (82,9\%), uzyskał motyw "chęć utrzymania dobrej kondycji fizycznej/ zdrowotnej".

\subsection{MOTYWACJE DO UDZIAŁU W PÓŁMARATONIE DWÓCH BADANYCH GRUP MĘŻCZYZN - RÓŻNICE}

W tabeli 2 przedstawiono pierwszą grupę motywów (A) - skierowaną na orientację społeczną, i drugą (B) - ukierunkowaną na orientację na emocje. Najważniejszym motywem z pierwszej grupy motywów, najczęściej wskazywanym zarówno przez biegaczy z Poznania, jak i turystów sportowych (odpowiednio 48,9\% i 49,8\%), była "chęć poczucia jedności i integracji z innymi ludźmi". Druga cytowana i statystycznie istotna $(p \leq 0,05)$ odpowiedź („,udział w subkulturze biegaczy”) okazała się waż- niejsza dla turystów sportowych niż dla biegaczy z Poznania (odpowiednio 19,4\% i 33,8\%). Przynależność do subkultury była również znacząca dla lokalnych biegaczy (1/5), choć zdecydowanie w mniejszym stopniu. Być może, jeśli potrzeba przynależności do subkultury jest silna, biegacze decydują się właśnie na udział w wydarzeniach poza miejscem stałego zamieszkania. W drugiej grupie motywów (B) najważniejsza i statystycznie istotna była "chęć przeżycia silnych emocji" - dla biegaczy z Poznania $(49,6 \%)$ i dla turystów sportowych $(74,4 \%)$. Wysoki odsetek turystów sportowych wskazujących ten motyw potwierdza, że podróżują oni w poszukiwaniu silnych wrażeń i emocji. Kolejnym ważnym motywem w tej grupie była "chęć dobrej zabawy" (56,1\% - mieszkańcy i 49,3\% - turyści).

Przegląd literatury (Kazimierczak, Malchrowicz-Mośko, 2013; Schwark 2006; Szczechowicz 2015) oraz przeprowadzone badania empiryczne pokazują, że turyści sportowi biorący aktywnie udział w półmaratonie są z niego bardziej zadowoleni niż uczestniczący w nim aktywnie mieszkańcy. Respondenci zostali dodatkowo poproszeni o określenie stopnia zadowolenia $\mathrm{z}$ udziału w imprezie za pomocą skali Likerta (1 - bardzo niezadowolony, 10 - bardzo zadowolony). Na kolejnej stronie zaprezentowano wyniki badań w zestawieniu porównującym ocenę biegaczy z Poznania biorących udział w półmartonie oraz turystów sportowych, którzy przybyli z innych miejscowości na to wydarzenie sportowe (tab. 3).

Tabela 2. Motywy mężczyzn uczestniczących w półmaratonie - o charakterze społecznym (A) i skierowane na doznanie przeżyć (B)

\begin{tabular}{|c|c|c|c|c|c|}
\hline \multirow{3}{*}{ Grupa motywów } & \multicolumn{4}{|c|}{ Mężczyźni } & \multirow{3}{*}{$P$} \\
\hline & \multicolumn{2}{|c|}{$\begin{array}{l}\text { mieszkańcy miasta } \\
\quad(\mathrm{n}=139)\end{array}$} & \multicolumn{2}{|c|}{$\begin{array}{l}\text { turyści sportowi } \\
\quad(\mathrm{n}=207)\end{array}$} & \\
\hline & $\mathrm{n}$ & $\%$ & $\mathrm{n}$ & $\%$ & \\
\hline \multicolumn{6}{|c|}{$\begin{array}{c}\text { Grupa A } \\
\text { Motywy w zakresie orientacji społecznej }\end{array}$} \\
\hline Pragnienie poczucia jedności i integracji z innymi ludźmi & 68 & 48,9 & 103 & 49,8 & 0,8786 \\
\hline Pragnienie poczucia równości podczas wyścigu & 26 & 18,7 & 41 & 19,8 & 0,7993 \\
\hline Panująca moda - udział w imprezach sportowych jest obecnie modny & 12 & 8,6 & 20 & 9,7 & 0,7461 \\
\hline Pragnienie zdobycia uznania w oczach innych & 25 & 18,0 & 45 & 21,7 & 0,3942 \\
\hline Przynależność do subkultury biegaczy & 27 & 19,4 & 70 & 33,8 & 0,0035 \\
\hline \multicolumn{6}{|c|}{$\begin{array}{c}\text { Grupa B } \\
\text { Motywy w zakresie orientacji na przeżycia }\end{array}$} \\
\hline Pragnienie przeżycia silnych emocji związanych ze startem & 69 & 49,6 & 154 & 74,4 & 0,0000 \\
\hline Pragnienie poczucia niezwykłej atmosfery panującej podczas całej imprezy & 64 & 46,0 & 100 & 48,3 & 0,6790 \\
\hline Pragnienie dobrej zabawy & 78 & 56,1 & 102 & 49,3 & 0,2119 \\
\hline Pragnienie spędzenia miło czasu / rozrywki & 39 & 28,1 & 54 & 26,1 & 0,6852 \\
\hline Pragnienie wyrażenia radości, np. z powodu wygranej/sukcesu & 32 & 23,0 & 30 & 14,5 & 0,0426 \\
\hline Pragnienie oderwania się od codzienności & 21 & 15,1 & 40 & 19,3 & 0,3131 \\
\hline Przyciągająca atrakcyjność miasta, w którym impreza się odbywa & 3 & 2,2 & 16 & 7,7 & 0,0257 \\
\hline
\end{tabular}

Źródło: opracowanie własne na podstawie przeprowadzonych badań ( $\mathrm{n}=346)$. 
Tabela 3. Odczuwanie satysfakcji uczestników półmaratonu: mieszkańców Poznania i turystów sportowych

\begin{tabular}{|c|c|c|c|c|c|c|c|}
\hline \multicolumn{4}{|c|}{ Biegacze $\mathrm{z}$ Poznania: $\mathrm{n}=139$} & \multicolumn{3}{|c|}{ Turyści sportowi: $\mathrm{n}=207$} & \multirow{2}{*}{$\mathrm{Z}$} \\
\cline { 1 - 5 } średnia & mediana & $\begin{array}{c}\text { odchylenie } \\
\text { standardowe }\end{array}$ & średnia & mediana & $\begin{array}{c}\text { odchylenie } \\
\text { standardowe }\end{array}$ & \\
\hline 8,0 & 8,0 & 1,4 & 9,0 & 9,0 & 1,2 & 9,3 & 0,0000 \\
\hline
\end{tabular}

Objaśnienia: Z - test U Manna Whitneya, $p$ - istotność statystyczna.

Źródło: opracowanie własne na podstawie przeprowadzonych badań (n=346).

Przeprowadzona analiza (test U Manna Whitneya) wykazała istnienie statystycznie istotnych różnic między poziomem zadowolenia lokalnych zawodników i turystów sportowych $(Z=9,3, p=0,0000)$. Porównanie średnich arytmetycznych i median w obu grupach pokazuje, że turyści byli bardziej zadowoleni z uczestnictwa w biegu niż mieszkańcy Poznania. Wśród ankietowanych biegaczy z Poznania średnia i mediana wyniosły tyle samo, tj. po 8 pkt., w grupie turystów wyniki te były dokładnie o 1 pkt wyższe. Ponadto zapytano turystów sportowych, czy ich zdaniem aktywność sportowa, która nie jest podejmowana $\mathrm{w}$ miejscu zamieszkania, dostarcza im silniejszych i bardziej pozytywnych emocji niż uprawianie sportu w miejscowości, w której osiedlili się na stałe. Wyniki pokazały, że tak było w przypadku $86 \%$ turystów sportowych. Może to sugerować, że turystyka sportowa zapewnia więcej możliwości doznawania intensywnych przeżyć na poziomie emocjonalnym niż sport uprawiany $w$ tradycyjnych warunkach $w$ miejscu zamieszkania. Respondentów, którzy odpowiedzieli „tak" na postawione pytanie $(\mathrm{n}=179)$, zapytano również o to, jak wysoko oceniają wzmaganie emocji przez aktywność poza miejscem zamieszkania. Zastosowano skalę odpowiedzi: 10 - bardzo wysoka, 1 - bardzo niska. Średnia wyniosła 9,0. Należy również dodać, że wynik ten nie miał związku z założonym i osiągniętym przez turystów startujących w półmaratonie celem sportowym. Biegnący mieszkańcy częściej odpowiadali, że osiągnęli cel sportowy $(74,3 \%)$, niż turyści sportowi (64\%).

W tabeli 4 przedstawiono uzyskany odsetek motywów do orientacji rzeczowej, czyli odnoszących się do samych wydarzeń sportowych i ich specyfiki (grupa C), a także do orientacji na wynik (grupa D) i innych motywów (grupa E). W grupie C najczęściej wskazywano "chęć rozwijania pasji związanej z bieganiem" - mieszkańcy Poznania w udziale 71,9\%, a turyści sportowi - $71,0 \%$. W tej grupie motywów nie znaleziono statystycznie istotnych różnic między badanymi grupami maratończyków. Najważniejszym motywem z grupy D dla wszystkich respondentów okazała się „,chęć sprawdzenia siebie" (mieszkańcy - 77,7\%, turyści - 70,5\%). Kolejnym ważnym motywem spośród wymienionych w grupie D dla obu badanych grup mężczyzn była "chęć osiągnięcia deklarowanego celu" (mieszkańcy - 58,3\%,

Tabela 4. Motywy mężczyzn - uczestników półmaratonu w zakresie orientacji rzeczowej

(odnoszące się do konkretnego wydarzenia sportowego i jego specyfiki), orientacji na wynik oraz pozostałych motywów

\begin{tabular}{|c|c|c|c|c|c|}
\hline \multirow[t]{2}{*}{ Grupy motywów } & \multicolumn{2}{|c|}{$\begin{array}{l}\text { Mieszkańcy Poznania } \\
\quad(\mathrm{n}=139)\end{array}$} & \multicolumn{2}{|c|}{$\begin{array}{l}\text { Turyści sportowi } \\
\quad(\mathrm{n}=207)\end{array}$} & \multirow[t]{2}{*}{$p$} \\
\hline & $\mathrm{n}$ & $\%$ & $\mathrm{n}$ & $\%$ & \\
\hline \multicolumn{6}{|c|}{$\begin{array}{c}\text { Grupa C } \\
\text { Motywy w zakresie orientacji rzeczowej (skierowane na konkretną dyscyplinę sportową) }\end{array}$} \\
\hline Pragnienie rozwijania pasji & 100 & 71,9 & 147 & 71,0 & 0,8515 \\
\hline Przyciągająca atrakcyjność sportowej części półmaratonu & 38 & 27,3 & 63 & 30,4 & 0,5345 \\
\hline $\begin{array}{l}\text { Przyciągająca atrakcyjność imprezy z powodu bogatego programu im- } \\
\text { prez towarzyszących }\end{array}$ & 13 & 9,4 & 24 & 11,6 & 0,5083 \\
\hline \multicolumn{6}{|c|}{$\begin{array}{c}\text { Grupa D } \\
\text { Motywy w zakresie orientacji na wynik }\end{array}$} \\
\hline Pragnienie sprawdzenia siebie & 108 & 77,7 & 146 & 70,5 & 0,1391 \\
\hline Pragnienie osiągnięcia wyznaczonego przez siebie celu & 81 & 58,3 & 131 & 63,3 & 0,3482 \\
\hline Pragnienie udziału w rywalizacji sportowej & 57 & 41,0 & 85 & 41,1 & 0,9918 \\
\hline Pragnienie wygranej & 1 & 7,0 & 7 & 3,4 & 0,1062 \\
\hline Wysoka (międzynarodowa) ranga imprezy sportowej & 1 & 7,0 & 13 & 6,3 & 0,0101 \\
\hline \multicolumn{6}{|c|}{$\begin{array}{c}\text { Grupa E } \\
\text { Pozostałe motywy }\end{array}$} \\
\hline Pragnienie utrzymania dobrej kondycji fizycznej oraz zdrowotnej & 114 & 82,0 & 173 & 83,6 & 0,7052 \\
\hline
\end{tabular}

Objaśnienie: $p$ - istotność statystyczna.

Źródło: opracowanie własne na podstawie przeprowadzonych badań (n = 346). 
turyści - 63,3\%), ale także „chęć uczestnictwa w rywalizacji sportowej" (41,0\% dla mieszkańców i 41,1\% dla turystów). Istotną statystycznie różnicę między tymi dwiema grupami ankietowanych stwierdzono $\mathrm{w}$ grupie motywów D w odniesieniu do odpowiedzi: „wysoka (międzynarodowa) pozycja tego wydarzenia sportowego" $(p<0,05)$. "Chęć wygranej” nie była tak ważna.

W ostatniej grupie motywów (E) najważniejsza była „chęć utrzymania kondycji fizycznej/zdrowotnej" dla startujących w półmaratonie biegaczy z Poznania (82,0\%), a także turystów sportowych $(83,6 \%)$. Nie stwierdzono istotnej różnicy w odpowiedziach uczestników. Respondentów zapytano o to, która grupa motywów była dla nich najważniejsza. Na rys. 1 przedstawiono odsetek poszczególnych grup motywów do wzięcia udziału w półmaratonie dla obu grup respondentów. Najistotniejsza dla turystów sportowych okazała się grupa B: „Motywy oparte na poszukiwaniu silnych emocji" $(39,6 \%)$, co stanowi potwierdzenie wcześniejszego wniosku, że turyści sportowi podróżują w poszukiwaniu takich wrażeń. Dla mieszkańców miasta $(40,3 \%)$ najważniejsza była grupa D, czyli: „Motywy zorientowane na wynik” - rozumiane jako znaczenie udziału w zawodach i rywalizacji lub sprawdzenia siebie. „Chęć utrzymania kondycji fizycznej/ zdrowotnej” (grupa E) nie była tak ważna dla biegaczy z Poznania.

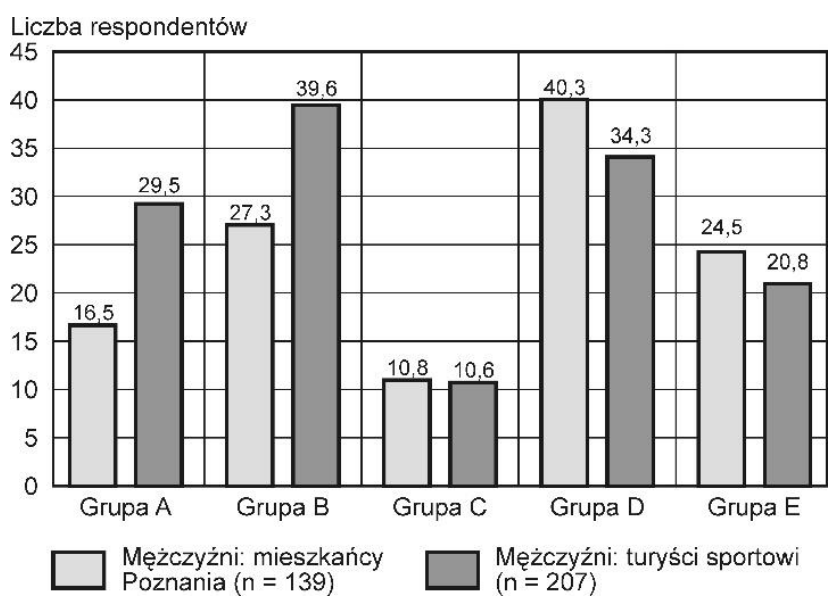

Rysunek 1. Najważniejsza grupa motywów do wzięcia udziału w półmaratonie w Poznaniu w przypadku ankietowanych mężczyzn: mieszkańców miasta oraz turystów sportowych Źródło: opracowanie własne na podstawie przeprowadzonych badań $(n=346)$

Najmniej istotna dla biegaczy mieszkających w Poznaniu oraz turystów sportowych była grupa $\mathrm{C}$ - motywy uczestniczenia w półmaratonie ze względu na określoną dyscyplinę sportową (mieszkańcy - 10,8\%, turyści - 10,6\%). Jednak wyniki badań wykazały coś zaskakującego, a mianowicie, że wszystkie inne motywy są ważniejsze niż bieg i jego organizacja. Jest to o tyle zadziwiające, że impreza ta to przede wszystkim bieg. Okazuje się, że wybór tego wydarzenia nie jest związany głównie z pasją do biegania oraz z zachowaniem zdrowia i kondycji fizycznej. Wynik ten stanowi konceptualizację turystyki imprez sportowych $\mathrm{w}$ wymiarze interakcji społecznych i psychologicznych, które ujawniają i pokazują jej twórcze warstwy oraz współczesne znaczenie, które już wykroczyło daleko poza funkcje zaspokajania potrzeby biegania lub dbania o zdrowie i kondycję fizyczną.

\section{DYSKUSJA I WNIOSKI KOŃCOWE}

W wyniku przeprowadzonych badań opracowano profil mężczyzny biegającego w półmaratonach. Typowy uczestnik takiego wydarzenia sportowego to osoba młoda i dobrze wykształcona. Spośród ankietowanych mężczyzn biorących udział w półmaratonie w Poznaniu najwięcej było uczestników w wieku 19-35 lat, większość miała wykształcenie wyższe i pochodziła z obszarów miejskich oraz była aktywna zawodowo. Uzyskany profil okazał się zgodny z wynikami badań przeprowadzonych w USA przez Rossa (2001). W odniesieniu do motywacji do udziału w maratonach wyniki badań uzyskane przez autorki niniejszego artykułu są podobne do zaprezentowanych w pracy Oglesa i Mastersa (1995), w której wykazano, że mężczyźni zwykle biegają z takich powodów, jak: chęć uczestnictwa w rywalizacji, osiągania sukcesów, wygrywania z przeciwnikiem lub z sobą.

Najczęściej zgłaszanym motywem była chęć dbania o zdrowie i kondycje fizyczną $(82,9 \%)$ oraz potrzeba sprawdzenia siebie $(73,4 \%)$. Zorientowanie na wynik było także najważniejszą grupą motywów (D) - dla 40,3\% biegaczy z Poznania biorących udział w półmaratonie. Pozostałe motywy również zostały ocenione wysoko. Najczęściej wskazywanym przez wszystkich biegaczy motywem z pierwszej grupy (A) była chęć poczucia jedności i integracji z innymi ludźmi, $w$ drugiej grupie motywów (B) najważniejsza okazała się chęć przeżywania silnych emocji związanych $\mathrm{z}$ uczestnictwem $\mathrm{w}$ zawodach. Trzecia grupa motywów (C) pokazuje, że dla mężczyzn biorących udział w półmaratonie najważniejsza jest chęć rozwijania pasji związanej z bieganiem. Wyniki analizy ostatniej grupy motywów (D) pokazują natomiast, że najważniejsza dla respondentów była chęć sprawdzenia siebie, którą należy uznać za najistotniejszy motyw spośród wszystkich grup motywów. Kolejnym motywem, który był ważny w grupie D, była chęć osiągnięcia założonego celu. Motyw z grupy E, czyli „Chęć utrzymania kondycji fizycznej i zdrowotnej", wskazała największa liczba respondentów (287). Ponadto motyw wygrywania $\mathrm{z}$ innymi nie był tak ważny jak motyw walki ze sobą i własnymi słabościami.

Badania służące ocenie różnych motywacji, które prowadzą do udziału w półmaratonie w Poznaniu w dwóch grupach mężczyzn: mieszkańców i turystów sportowych, 
prowadzą do kilku wniosków. Najważniejszym motywem z pierwszej grupy (A) - najczęściej wskazywanym zarówno przez biegnących mieszkańców, jak i turystów sportowych - była chęć poczucia jedności i integracji $z$ innymi ludźmi. Drugą statystycznie istotną $(p \leq 0,05)$ odpowiedzią było to, że udział w subkulturze biegaczy okazał się ważniejszy dla turystów sportowych niż dla biegaczy z Poznania. W drugiej grupie motywów (B) najważniejsze i statystycznie znaczące wskazanie dla obu grup respondentów stanowiła chęć przeżywania silnych emocji. Kolejnym ważnym motywem również dla obu badanych grup była chęć dobrej zabawy. Motyw związany z potrzebą przeżywania silnych emocji był ważniejszy dla turystów sportowych, co potwierdza wcześniejszy wniosek, że turyści sportowi podróżują $\mathrm{w}$ poszukiwaniu silnych wrażeń.

Wyniki te wyraźnie pokazują, że miłośnicy sportu podróżują na imprezy masowe $\mathrm{w}$ poszukiwaniu emocji oraz w celu budowania relacji społecznych. Popularność turystyki sportowej, a w tym przypadku turystyki maratonowej, można wytłumaczyć faktem, że jest ona przejawem aktywności społeczeństwa skupionego na przeżywaniu silnych emocji (Schulze, 1992), także podczas podróży. Ponadto należy dodać, że masowe wydarzenia sportowe stają się postmodernistyczną formą uczestnictwa w życiu społecznym - pozwalają poczuć się częścią określonej społeczności - biegaczy, maratończyków. Potrzeba przynależności jest niezwykle ważna w społeczeństwach zachodnich, które (w odróżnieniu od wschodnich) nie mają dzisiaj wielu możliwości zachowań kolektywistycznych. W obliczu osłabienia tradycyjnych środowisk społecznych $w$ kulturach zachodnich i postępującej indywidualizacji społeczeństwa, jednostka - nie chcąc być samowystarczalna - szuka aktywnie nowych struktur społecznych dla siebie. Ludzie poszukują kontaktu z innymi, którzy mają podobny styl życia oraz zbliżone zainteresowania i poglądy. Fizyczna obecność innych, zdolność do wizualnego i namacalnego potwierdzenia ich istnienia zapewnia, że tak się dzieje pod wpływem indywidualnie wybranego stylu życia. Okazją do takich spotkań są m.in. wydarzenia sportowe.

Udział w wydarzeniu sportowym zazwyczaj wiąże się z silnym poczuciem wspólnoty z innymi uczestnikami, pozwala na dzielenie się emocjami z ludźmi będącymi w pobliżu. We współczesnym świecie, w którym obserwujemy trend do autonomizacji społeczeństwa (w którym człowiek doznaje samotności), z zanikiem tradycyjnych zachowań oraz problemów z nawiązywaniem i utrzymywaniem relacji interpersonalnych, wydarzenia sportowe stwarzają możliwość budowania relacji społecznych i tożsamości społecznej. Zduniak (2010) zakłada jednak, że takie wydarzenia są zwykle krótkotrwałe, ulotne. Zapewniają samotnym osobom bezpośrednie poczucie bliskości z innymi, ale po zakończeniu tych eventów utworzona chwilowo społeczność zwykle już nie istnieje. Dlatego pojawia się silna potrzeba uczestnictwa w kolejnych wydarzeniach, które mogą być jednym z czynników dynamicznego rozwoju turystyki imprez sportowych. Ważnym aspektem jest również fakt, że praktycznie każdy może uczestniczyć w popularnych dziś wydarzeniach sportowych, w których przypadku uczestnicy nie muszą sprostać zbyt wielu wymaganiom. Ludzka potrzeba przynależności jest zatem zaspokojona praktycznie bez wysiłku. Człowiek nie musi dążyć do budowania tych relacji. Jedyne pytanie brzmi: $w$ jakim stopniu te wydarzenia naprawdę tworzą tę pożądaną społeczność oraz czy są to rzeczywiście spotkania samotnych osób? Być może są one jednak tylko ponowoczesnym rytuałem zbiorowej samotności (Cudowska, 2010; Zduniak, 2010).

Najczęściej wskazywaną podczas ankietyzacji odpowiedzią w grupie motywów $C$ była chęć rozwijania pasji, ważna zarówno dla badanych biegaczy z Poznania, jak i turystów sportowych (bez statystycznie istotnych różnic między grupami). Najważniejszymi motywami z grupy D dla obu grup respondentów (biegaczy z Poznania i turystów sportowych) była chęć sprawdzenia siebie (walka ze sobą), osiągnięcia założonego celu i uczestnictwa w zawodach sportowych. Stwierdzono istotną statystycznie różnicę między dwiema grupami respondentów w przypadku motywu: „wysoka (międzynarodowa) ranga tego wydarzenia sportowego" $(p<0,05)$. W ostatniej grupie motywów (E) najważniejsza była chęć utrzymania dobrego stanu fizycznego/zdrowotnego przez biegaczy z Poznania i turystów sportowych. Nie stwierdzono istotnej różnicy między wskazaniami uczestników badania z obu grup.

Najistotniejsza dla turystów sportowych okazała się grupa B, czyli „Motywy ukierunkowane na szukanie emocji", co potwierdza, że turyści sportowi podróżują w poszukiwaniu silnych przeżyć i wrażeń. Dla mieszkańców Poznania ważne były „motywy w zakresie orientacji na wynik" (grupa D) rozumiane jako znaczenie udziału w zawodach lub sprawdzenia siebie.

Najmniej istotną grupą motywów dla mieszkańców miasta i turystów sportowych była grupa C - motywy ukierunkowane na konkretną dyscyplinę sportu. Ten wynik pokazuje, że podczas gdy osoby uczestniczące w półmaratonach w swoim mieście koncentrują się na zagadnieniach ściśle związanych ze sportem, takich jak rywalizacja, to turystyka sportowa zapewnia biegaczom będącym jednocześnie turystami sportowymi, silne wrażenia i emocje. Ta potrzeba skłania ich bowiem głównie do podróżowania.

Niniejszy artykuł zawiera dane, które mogą być przydatne w organizacji wydarzeń sportowych (takich jak półmaraton) czy w marketingu miast. Wyniki dostarczają organizatorom informacji na temat profilu miłośników biegania, potrzeb biegaczy z Poznania oraz tego, czym można przyciągnąć turystów sportowych, organizując np. półmaraton. Duże znaczenie przypisano budowaniu relacji społecznych. Być może program im- 
prezy powinien zostać rozszerzony o inne atrakcje, aby biegacze mogli spędzać więcej czasu razem. $Z$ naukowego punktu widzenia wyniki pokazują różnicę między turystą sportowym a biegaczem, który bierze udział w wydarzeniu w mieście, w którym żyje.

Badanie pomaga $\mathrm{w}$ znalezieniu odpowiedzi na pytanie: dlaczego ludzie wybierają się na wycieczkę, aby wziąć udział w wydarzeniu sportowym i ćwiczyć fizycznie? Podczas gdy dla turystów sportowych najważniejsze były motywy orientacji ukierunkowanej na poszukiwanie wrażeń, szczególnie chęć przeżywania silnych emocji związanych z uczestnictwem, to dla biegaczy z Poznania najważniejsze były motywy ukierunkowane na wynik. Ponadto turyści sportowi szukali silnych emocji, a turystyka sportowa daje więcej możliwości przeżywania ich niż sport uprawiany w znanych mieszkańcom przestrzeniach.

Uzyskane wyniki potwierdzają również teorię Zuckermana (1994), w której autor podkreśla znaczenie przeżywania silnych emocji związanych z uczestnictwem w wydarzeniu sportowym, określając je jako poszukiwanie wrażeń. Badacz, doświadczając silnych emocji związanych z nastrojem danego wydarzenia, uważa to za jeden z najważniejszych czynników wpływających na wybór i skuteczność różnych form zajęć sportowych i rekreacyjnych. Szczególnie dla turystów sportowych ważne są silne odczucia i emocje związane z uczestnictwem $\mathrm{w}$ wydarzeniach sportowych. Poszukują oni bowiem również możliwości nawiązania relacji społecznych.

Niniejsze opracowanie stanowi konceptualizację turystyki imprez sportowych $w$ wymiarze interakcji społecznych i psychologicznych, ujawniających i demonstrujących jej twórcze płaszczyzny oraz współczesne znaczenie, które już wykroczyło daleko poza funkcje zaspokajania potrzeby biegania lub dbania o zdrowie i kondycję fizyczną. Lokalni biegacze koncentrują się na tematach związanych ze sportem, takich jak: rywalizacja, turystyka sportowa, co zapewnia turystom sportowym silne wrażenia i emocje, a ta potrzeba skłania ich głównie do podróżowania. Turystyka sportowa odsłania więcej możliwości doznawania intensywnych przeżyć na poziomie emocjonalnym niż sport uprawiany $\mathrm{w}$ tradycyjnych warunkach. Zdecydowanie wyniki te dostarczają wskazówek menedżerom sportu co do organizacji przyszłych imprez sportowych, ale - co najważniejsze - ułatwiają rozumienie motywów, którymi kierują się mężczyźni, uprawiając sport nieelitarny. Ważne jest również poznanie motywacji kobiet, młodzieży i osób starszych. W przyszłości powinno się sprawdzić, czy kraj pochodzenia może wpływać na strukturę motywacyjną biegaczy - interesujące byłoby przeprowadzenie podobnych badań $\mathrm{w}$ innych krajach i dokonanie analizy porównawczej motywacji do udziału w biegach ulicznych na tle trendów społeczno-kulturowych charakterystycznych dla danego regionu.

\section{PRZYPIS}

${ }^{1}$ Opracowanie własne na podstawie danych organizatorów wydarzeń; wrzesień 2018 r.

\section{BIBLIOGRAFIA}

Aicher, T., Karadakis, K., Eddosary, M. (2015). Comparison of sports tourists' and locals' motivation to participate in a running event. International Journal of Event and Festival Management, 6 (3), 215-234.

Alexandris, K., Carroll, B. (1997). An analysis of leisure constraints based on different recreational sports levels: Results from a study in Greece. Leisure Science, 19 (1), 1-15.

Alexandris, K., Tsorbatzoudis, Ch., Grouios, G. (2002). Perceived constraints on recreational sports participation: Investigating their relationship with intrinsic motivation, extrinsic motivation and amotivation. Journal of Leisure Research, 2 (34), 233-252.

Biernat, E., Piątkowska, M. (2012). Rekreacyjna aktywność fizyczna Polaków na tle Europy. Warszawa: Ministerstwo Sportu i Turystyki.

Briere, N.M., Vallerand, R.J., Blais, M., Pelletier, L.G. (1995). Developpement et validation d'une mesure de motivation intrinseque et extrinseque et d'amotivation en contexte sportsif: L'Echelle de Motivation vis-à-vis les Sports (EMS). International Journal of Sports Psychology, 4 (26), 465-489.

Carmack, M.A., Martens, R. (1979). Measuring commitment to running: A survey of runners' attitudes and mental states. Journal of Sports Psychology, 1 (1), 25-42.

Chappelet, J.L. (2015). Heritage sporting events and place marketing W: M. Plevnik (red.), Sustainable development of sports tourism. Koper: Annales University Press.

Clough, P.J., Sheper, J., Maugha, R. (1989). Motives for participation in recreational running. Journal of Leisure Research, 21 (4), 297-309.

Crawford, R. (1977). You are dangerous to your health: The ideology and politics of victim blaming. International Journal of Health Services, 7 (4), 663-680.

Crawford, R. (1980). Healthism and the medicalization of everyday life. International Journal of Health Services, 10 (3), 365-388.

Crawford, R. (1994). The boundaries of the self and the unhealthy other: Reflections on health, culture and AIDS. Social Science and Medicine, 38 (10), 1347-1365.

Crawford, R. (2004). Risk ritual and the management of anxiety in medical culture. Health: An Interdisciplinary Journal for the Social Study of Health, Illness and Medicine, 8 (4), 505-552.

Crawford, R. (2006). Health as a meaningful social practice. Health: An Interdisciplinary Journal for the Social Study of Health, Illness and Medicine, 10 (4), 401-420.

Crowne, D.P., Marlowe, D. (1960). A new scale of social desirability independent of psychopathology. Journal of Consulting Psychology, 24 (4), 349-354.

Cudowska, A. (2010). Wspólnota w kulturze indywidualizmu. Pobrane z: https://repozytorium.uwb.edu.pl/jspui/bitstream/ 11320/2729/1/Agata\%20Cudowska_Wsp\%c3\%b3lnota\%20w \%20kulturze\%20indywidualizmu.pdf (13.08.2019).

Curtis, J., McTeer, W. (1981). The motivation for running. Canadian Runners, 1, 18-19.

De Pero, R., Amici, S., Benvenuti, C., Minganti, C., Capranica, L., Pesce, C. (2009). Motivation for sports participation in older Italian athletes: The role of age, gender and competition level. Sports Science and Health, 5 (2), 61-69. 
Deci, E.L. (1975). Intrinsic motivation. New York: Plenum.

Deci, E.L., Ryan, R.M. (1985). Intrinsic motivation and self-determination in human behavior. New York: Plenum Press.

Deci, E.L., Ryan, R.M. (1991). A motivational approach to self: Integration in personality. W: R. Dienstbier (red.), Nebraska symposium on motivation: Perspectives on motivation. Tom 38 (s. 237288). Lincoln, NE: University of Nebraska Press.

Deci, E.L., Ryan, R.M. (2000). Intrinsic and extrinsic motivations: classic definitions and new directions. Contemporary Educational Psychology, 25 (1), 54-67.

Deci, E.L. Ryan, R.M. (2000). The „what” and "why” of goal pursuits: Human needs and the self-determination of behavior. Psychological Inquiry, 11 (4), 227-268.

Doganis, G. (2000). Development of a Greek version of the sports motivation scale. Perceptual and Motor Skills, 90 (2), 505-512.

Domański, H. (2000). Polska klasa średnia. Wrocław: Wydawnictwo Uniwersytetu Wrocławskiego.

Freyer, W., Gross, S. (2002). Tourismus und Sport-Events. Dresden: FIT Forschungsinstitut für Tourismus.

Gibson, H., Kaplanidou, K., Kang, S.J. (2012). Small-scale event sports tourism: A case study in sustainable tourism. Sports Management Review, 15 (2), 160-170.

Gill, D.L., Deeter, T.E. (1988). The development of the sports orientation questionnaire. Research Quarterly for Exercice and Sports, 59 (3), 191-202.

Johnsgård, K. (1985). The motivation of the long distance runner. Journal of Sports Medicine, 25, 135-139.

Kazimierczak, M., Malchrowicz-Mośko, E. (2013). Specific and developmental trends of sports tourism. Folia Turistica, 28, 67-90.

Lenartowicz, M., Dziubiński, Z., Jankowski, K. (2017). Aktywni Polacy: dwie dekady uczestnictwa w sporcie i rekreacji ruchowej. Próby wyjaśnienia zmian. Kultura i Społeczeństwo, 2, 117-132.

Masters, K.S., Lambert, M.J. (1989). The relation between cognitive coping strategies, reasons for running, injury, and performance of marathon runners. Journal of Sports and Exercise Psychology, 11, 161-170.

Masters, K.S., Ogles, B.M., Jolton, J.A. (1993). The development of an instrument to measure motivation for marathon running: The motivation of marathoners scales (MoMS). Research Quarterly for Exercise and Sports, 64 (2), 134-143.

Ogles, B.M., Masters, K.S. (2003). A typology of marathon runners based on cluster analysis on motivations. Journal of Sports Behaviour, 26 (1), 69-85.

Ogles, B.M., Masters, K.S., Richardson, S.A. (1995). Obligatory running and gender: An analysis of participative motives and training habits. International Journal of Sports Psychology, 26, 233248.

Papanikos, G. (2015). The economic effects of a marathon as a sports tourism event. Athens Journal of Sports, 1 (225), 225-240.

Pelletier, L.G.; Tuson, K.M.; Fortier, M.S.; Vallerand, R.J.; Briere, N.M.; Blais, M.R. (1995). Toward a New Measure of Intrinsic Motivation, Ex Motivation and Amotivation in Sports. J. Sport Exerc. Psychol, 17, 35-53.

Raport „Aktywność fizyczna Polaków TNS Polska” (2015). Warszawa: TNS.

Roberts, C. (2011). Sports and adventure tourism. W: P. Robinson, S. Heitmann, P. Dicke (red.), Research themes for tourism. Oxfordshire-Cambridge, UK: CABI Publisher.

Ross, D. (2001). What are the characteristics of sport tourists? W: D. Ross (red.), Developing sports tourism. National Laboratory for Tourism. Urbana - Champaign, Illinois: University of Illinois.

Ryan, M.R. (1995). Psychological needs and the facilitation of integrative processes. Journal of Personality, 63 (3), 397-427.
Ryan, R.M. Deci, E.L. (2000). Self-determination theory and the facilitation of intrinsic motivation, social development, and wellbeing. The American Psychologist, 55 (1), 68-78.

Ryan, R.M. La Guardia, J.G. (2000). What is being optimized over development? A self-determination theory perspective on basic psychological needs across the life span. W: S. Qualls, N. Abeles (red.), Psychology and the aging revolution (s. 145-172). Washington: APA Books.

Schulze, G. (1992). Die Erlebnisgesellschaft. Kultursoziologie der Gegenwart, Frankfurt am Main: Campus-Verlag.

Schwark, J. (2006) Grundlagen zum Sporttourismus. Münster-New York-München-Berlin: Waxmann.

Stempień, J.R. (2015). Polska moda na bieganie w świetle analizy kohort. Perspektywa socjologiczna. W: M. Zowisło, J. Kosiewicz (red.), Sport i turystyka w zwierciadle wartości społecznych (s. 450-460). Kraków: Wydawnictwo Akademii Wychowania Fizycznego w Krakowie.

Stempień, J.R. (2016). Bieganie, zwiedzanie i klasa średnia - przygarść socjologicznych uwag i obserwacji o turystyce biegowej. W: M. Kazimierczak (red.), Inspiracje sportem w turystyce kulturowej (s. 39-49). Poznań: Wydawnictwo Akademii Wychowania Fizycznego w Poznaniu.

Summers, J.J., Sargent, G.I., Levey, A.J., Murray, K.D. (1982). Middle aged, non-elite marathon runners: A profile. Perceptual and Motor Skills, 54 (3), 963-969.

Szczechowicz, B. (2015). Łączenie wartości turystyki i sportu w świetle analizy ofert rynkowych. W: M. Kazimierczak (red.), Turystyka sportowa - społeczno-kulturowy potencjat i perspektywy rozwoju (s. 41-53). Poznań: Wydawnictwo Akademii Wychowania Fizycznego w Poznaniu.

Taks, M. (2013). Social sustainability of non-mega sports events in a global world. European Journal for Sports and Society, 10 (2), 121-141.

Taks, M., Green, Ch., Misener, L., Chalip, L. (2014). Evaluating sports development outcomes: The case of a medium-sized international sports event. European Sports Management Quarterly, 14 (3), 213-237.

Vallerand, R.J. (1997). Toward a hierarchical model of intrinsic and extrinsic motivation. W: M.P. Zanna (red.), Advances in experimental social psychology. Tom 29 (s. 271-360). San Diego, CA: Academic Press.

Vallerand, R.J., Deci, E.L., Ryan, R.M. (1987). Intrinsic motivation in sports. W: K.B. Pandolf (red.), Exercise and sports sciences reviews. Tom 15 (s. 389-425). New York: MacMillan.

Vlachopoulos, S.P., Michailidou, S. (2006). Development and initial validation of a measure of autonomy, competence, and relatedness in exercise: The basic psychological needs in exercise scale. Measurement in Physical Education and Exercise Sciences, 10, 179-201.

Walczak, M. Tomczak, M. (2011). The structure of psychological determinants of selected aspects of physical activity in the light of the theory of self-determination. Sports and Recreation and the Challenge of Modern Civilization; Scientific Notebooks of Szczecin University, 689; Economic Issues Services, 78, 127-152.

Zduniak, A. (2010). Event jako ponowoczesna forma uczestnictwa w życiu społecznym. Roczniki Nauk Społecznych, 2 (38), 207-234.

Zuckerman, M. (1994) Behavioral expressions and biosocial bases of sensation seeking. New York: Cambridge Press.

Artykuł wpłynął:

3 września $2019 \mathrm{r}$.

Zaakceptowano do druku:

21 października $2019 \mathrm{r}$ 